\title{
RECORDS OF A MALE KILLER WHALE (ORCINUS ORCA) OFF SOUTHEASTERN BRAZIL
}

\author{
Marcos César de Oliveira Santos and Ednilson da Silva
}

Universidade Estadual Paulista "Júlio de Mesquita Filho" (UNESP) Instituto de Biociências, Departamento de Zoologia

Projeto Atlantis, Laboratório de Biologia da Conservação de Cetáceos (Campus Rio Claro, Av. 24-A, 1.515, Bela Vista, 13506-900 Rio Claro, SP, Brasil)

\section{E-mail: sotalia@gmail.com}

Killer whales (Orcinus orca) are found in all oceans, but are generally most commonly observed in coastal, temperate waters, especially in areas of high productivity (HEYNING; DAHLHEIM, 1988; FORD, 2002). In the Western South Atlantic (WSA), longterm studies on killer whales have been conducted only off northern Patagonia, Argentina (see LÓPEZ; LÓPEZ, 1985; HOELZEL, 1991; IÑÍGUEZ, 2001). The species is poorly known on the Brazilian coast where strandings and opportunistic sightings are the main sources of information (see review in SANTOS; NETTO, 2005). The only known short-term study was undertaken in the 1990s to quantify killer whale predation on longline fisheries (SECCHI; VASKE JR., 1998). Information on $O$. orca abundance, distribution and movements along the Brazilian coast is, therefore, scarce. We here report four sightings of a male killer whale, presenting the first observation on a longdistance movement along the southeastern coast of Brazil.

The first sighting occurred on 22 March 2005 in coastal waters off Paraná and São Paulo States (Fig. 1) and was described by SANTOS; NETTO (2005). On that occasion, the predation on a franciscana dolphin (Pontoporia blainvillei) was observed. In the several photographs taken of the male

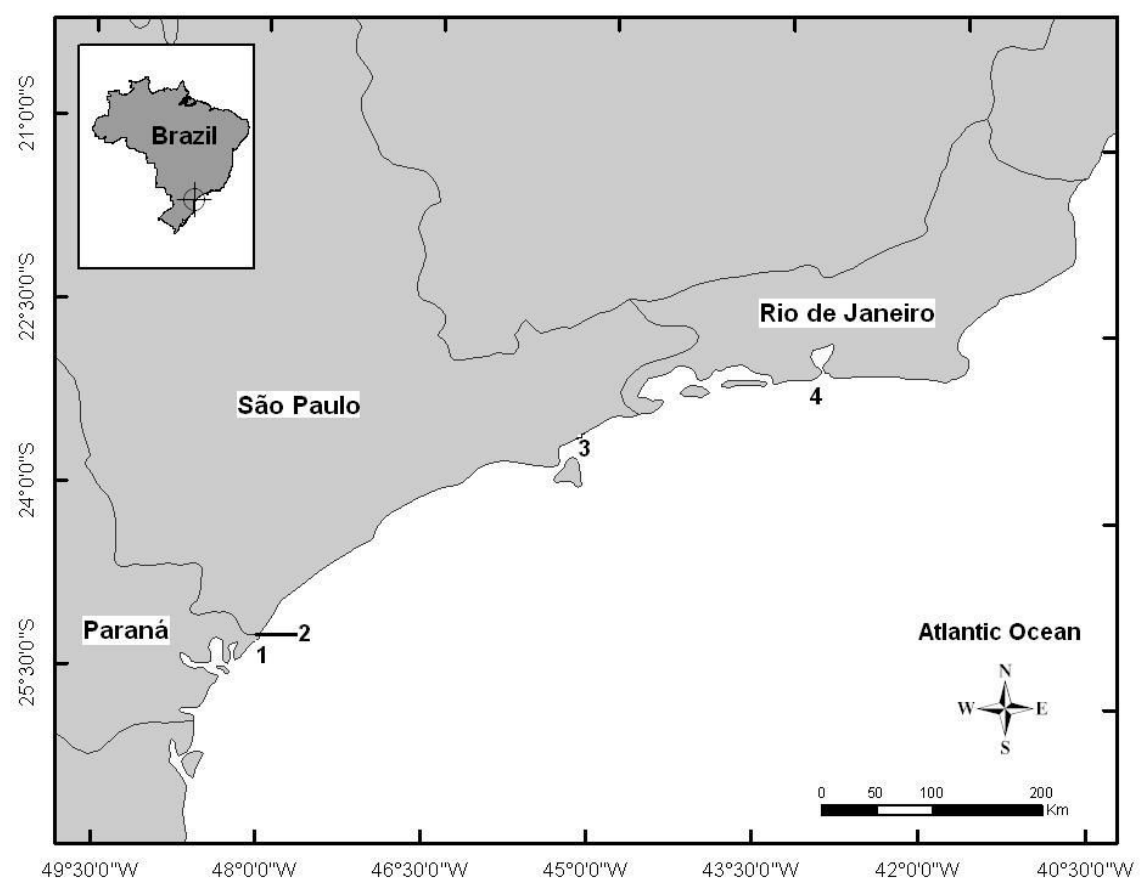

Fig. 1. Map showing the exact locations of the four distinct sightings of a male killer whale (Orcinus orca) in southeastern Brazil between March 2005 and May 2008. Sequence numbers accord with the data presented in Table 1. 
dorsal fin, it was possible to distinguish a big notch in the upper third of the fin, as well as a smaller one slightly lower down (Fig. 2). On 10 September 2007, 30 months after the first sighting, the same individual was re-sighted in the main entrance to the Cananéia estuary (Table 1), São Paulo State. The killer whale approached the northern coast of the Ilha do Cardoso in inner estuarine waters (Fig. 1), leaving for the coastal waters after about one hour. Two boats followed the individual sighted, but most of the photographs were taken from considerable distances. The best photograph showed the same distinct notches as the male sighted in March 2005. This is the only known record of a killer whale so far registered in the Cananéia estuary. On 8 February 2008, the same individual was observed off Barra do Una (Table 1), on the northern coast of São Paulo State. It spent around 2 hours close to the shore and left on the same day. The killer whale was recognized as the same individual through a video footage made by a local inhabitant. Recently, on 3 May 2008, the same individual was observed off Barra da Tijuca (Table 1), Rio de Janeiro. Photographs taken by a local newspaper photographer proved its identity. On all these occasions, the male killer whale was observed very close to the shore, was alone and was followed by boats to the presence of which it did not react except to avoid collisions. No contacts with humans were reported.

Long-distance movements of killer whales are known to occur in several ocean basins, ranging from $750 \mathrm{~km}$ off Alaska (MATKIN et al., 1997) and 2,600 km from Alaska to California (GOLEY; STRALEY, 1994) to $15,600 \mathrm{~km}$ in New Zealand waters (VISSER, 1999). In the WSA, long-distance movements of killer whales were observed in northern Patagonia, ranging between 60 and $450 \mathrm{~km}$ (IÑÍGUEZ, 2001). The killer whale tracked off southeastern Brazil, in the light of the first and last sightings made, covered a minimum distance of approximately $550 \mathrm{~km}$. The last re-sighting occurred 38 months after the first observation of the whale in March 2005. All the sightings were opportunistic and likely to have been made because of the close proximity of the individual to the densely populated coast. As no sightings have been reported at other locations we have only been able to estimate the minimum possible distance traveled.

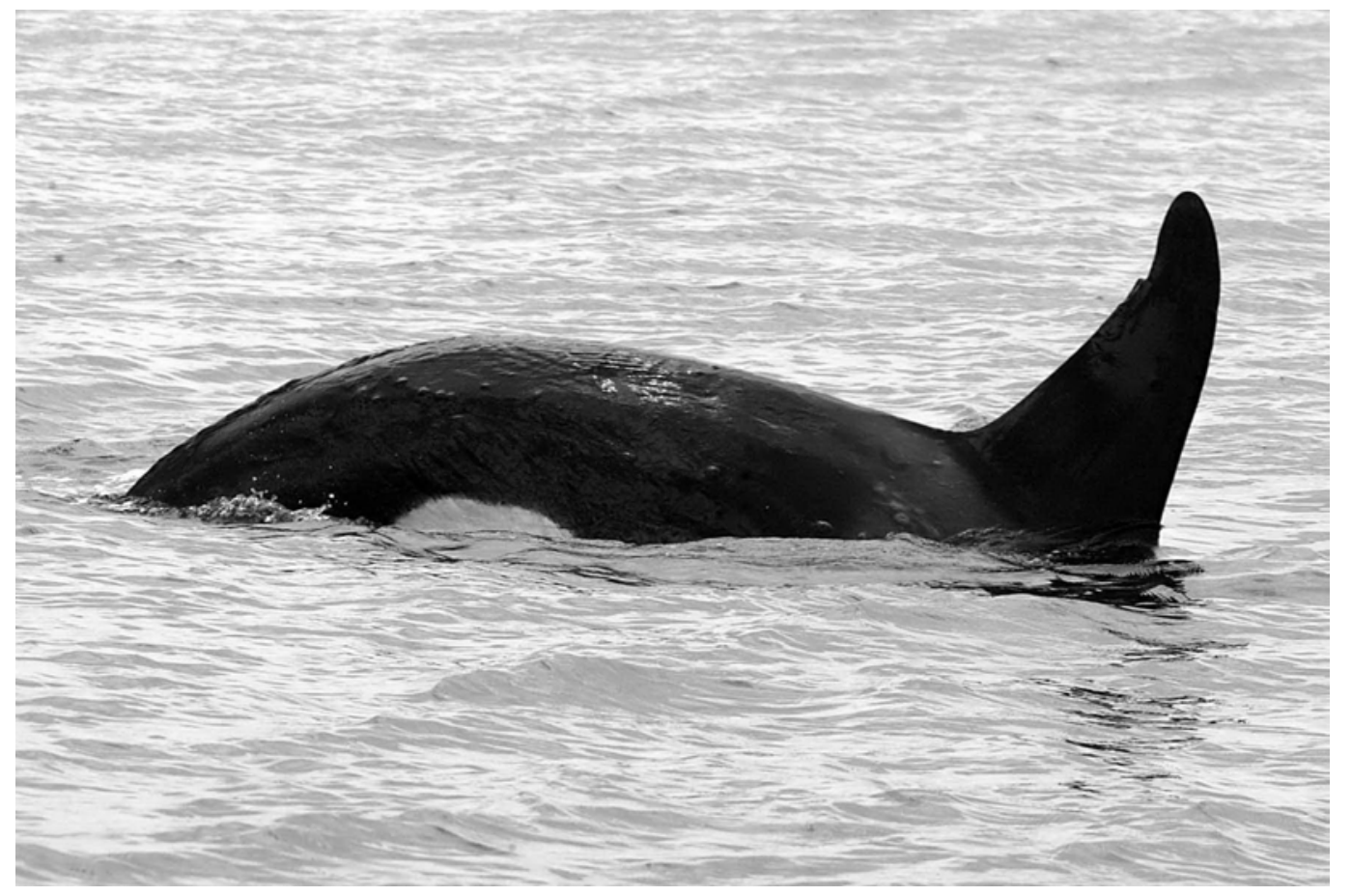

Fig. 2. Male killer whale (Orcinus orca) observed on four distinct occasions along the southeastern coast of Brazil. The big notch may be observed on the border of the dorsal fin as also the smaller just below it. 
Table 1. Sightings of a male killer whale (Orcinus orca) along the Brazilian southeastern coast between 2005 and 2008 .

\begin{tabular}{lccc}
\hline \hline (\# of Sighting) Date & Location & Water Depth (m) & $\begin{array}{c}\text { Distance from } \\
\text { the coast (m) }\end{array}$ \\
\hline (1) 22 March 2005 & $25^{\circ} 20^{\prime} \mathrm{S}, 45^{\circ} 05^{\prime} \mathrm{W}$ & $8-10$ & 8,000 \\
(2) 10 September 2007 & $25^{\circ} 03^{\prime} \mathrm{S}, 47^{\circ} 55^{\prime} \mathrm{W}$ & $14-23$ & inner estuarine \\
(3) 8 February 2008 & $23^{\circ} 25^{\prime} \mathrm{S}, 44^{\circ} 58^{\prime} \mathrm{W}$ & $<25$ & $80-2,000$ \\
(4) 3 May 2008 & $22^{\circ} 56^{\prime} \mathrm{S}, 43^{\circ} 30^{\prime} \mathrm{W}$ & $<15$ & $100-4,000$ \\
\hline
\end{tabular}

The search for prey in shallow waters could be listed as a possible reason for the observation of this killer whale close to the shore. On 22 February 1996, at least 10 killer whales were witnessed engaged in the predation of manta rays (Manta birostris) in shallow waters off the northern coast of São Paulo State (LODI; HETZEL, 1988). Coastal dwelling franciscana dolphins, usually found in shallow waters, were also listed as killer whale food items on the coast of Brazil (OTT; DANILEWICZ, 1997; SANTOS; NETTO, 2005). On 23 January 2007, an unusual sighting of three franciscana dolphins was reported in the inner waters of the Cananéia estuary (SANTOS et al., 2007). When discussing the possible reasons for such an unusual sighting, the authors suggested that they may have been seeking shelter in protected areas from top predators such as killer whales. Guiana dolphins (Sotalia guianensis) are year-round residents in the above-mentioned estuary (SANTOS et al., 2001; SANTOS; ROSSO, 2008), but no interactions with the male killer whale were observed on 10 September 2007. No $O$. orca predation on $S$. guianensis has ever been reported, but killer whale sightings in the distribution range of the latter may represent a clue to such interaction. The predation pressure coming from killer whales must be considered when listing the reasons why $S$. guianensis groups are usually confined to shallow bays, river mouths and protected estuaries commonly associated with turbid waters (see SICILIANO et al., 1999). Besides killer whales, sharks may also play an important role in $S$. guianensis distribution patterns (see SANTOS; ROSSO, 2007).

Based on several distinct parameters including feeding habits, different populations and/or ecotypes of killer whales have been described elsewhere (e.g. BIGG et al., 1990; BAIRD et al., 1992; FORD et al., 1994; PITMAN; ENSOR, 2003). In the northeast Pacific, transient killer whales are known to visit shallow waters in their search for marine mammals (BAIRD et al., 1992; FORD et al., 1994; FORD; ELLIS, 1999). When evaluating killer whale sighting data on the coast of Rio de Janeiro, SICILIANO et al. (1999) suggested that most records fulfilled the ecological requirements relating to transient killer whales (see BAIRD; DILL, 1995; 1996; FORD, 2002), i.e., small-sized groups (1-15), unpredictable seasonal occurrence, and foraging area generally in coastal waters. These seem to correspond to the patterns described in our four sightings. On the other hand, predation on rays by $O$. orca has also been reported in shallow waters (LODI; HETZEL, 1988; SICILIANO et al., 1999). Killer whales may take advantage of the local upwelling conditions and forage on a broader variety of seasonally abundant prey items (SICILIANO et al., 1999). It is clear that only on the basis of further data will it be possible better to understand the patterns of killer whale abundance, distribution and foraging habits in Brazilian waters. A first step would be the creation of an on-line catalog of individually recognized individuals to address additional re-sightings. Dorsal fin photographs are to be found in the hands of various researchers and should be brought together in one collection. New matches will represent important pieces for the solution of the puzzle of $O$. orca distribution patterns along the Brazilian coast.

\section{ACKNOWLEDGEMENTS}

Noeli Neves provided photographs of the killer whale in the Cananéia estuary, Adrian Fuhrhaussen provided the video footage taken in Barra do Una, and Hipólito Pereira of O Globo newspaper and Salvatore Siciliano provided photographs taken in Rio de Janeiro. The Projeto Atlantis has been sponsored by 
the following institutions: Cetacean Society International, Whale \& Dolphin Conservation Society, Earthwatch Institute and Fundação de Amparo à Pesquisa do Estado de São Paulo (FAPESP). The fieldwork had the support of the Instituto Oceanográfico da Universidade de São Paulo, Núcleo Pro-Ação (Pontifícia Universidade Católica do Paraná), and the Parque Estadual da Ilha do Cardoso (Instituto Florestal, SEMA-SP). We would also thank the two anonymous reviewers for their suggestions for the improvement of the manuscript.

\section{REFERENCES}

BAIRD, R. W.; DILL, L. M. Occurrence and behaviour of transient killer whales: seasonal and pod-specific variability, foraging behaviour, and prey handling. Can. J. Zool., v. 73, n. 7, p. 1300-1311, 1995.

BAIRD, R. W.; DILL, L. M. Ecological and social determinants of group size in transient killer whales. Behav. Ecol., v. 7, n.. 4, p. 408-416, 1996.

BAIRD, R. W.; ABRAMS, P. A.; DILL, L. M. Possible indirect interactions between transient and resident killer whales: implications for the evolution of foraging specializations in the genus Orcinus. Oecologia, v. 89, n. 1, p. 125-132, 1992.

BIGG, M. A.; OLESIUK, P. F.; ELLIS, G. M.; FORD, J. K. B.; BALCOMB III, K. C. Social organization and genealogy of resident killer whales (Orcinus orca) in the coastal waters of British Columbia and Washington State. Rept int. Whal. Commn, v. 12, p. 383-405, 1990. Special issue.

FORD, J. K .B. Killer whale Orcinus orca. In: PERRIN, W. F.; WÜRSIG, B.; THEWISSEN, J. G. M. (Ed.). Encyclopedia of marine mammals. San Diego, CA: Academic Press, 2002. p. 669-676.

FORD, J. K. B.; ELLIS, G. M. Transients: Mammalhunting orcas of British Columbia, Washington, and Southeastern Alaska. Vancouver, B.C.; Seattle, WA.: UBC Press; University of Washington Press, 1999. 96 p.

FORD, J. K. B.; ELLIS, G. M; BALCOMB, K. C. Killer Whales: The natural history and genealogy of Orcinus orca in British Columbia and Washington State. Vancouver, B.C. : University of British Columbia Press, 1994. $104 \mathrm{p}$

GOLEY, P. D.; STRALEY, J. M. Attack on grey whales in Monterrey Bay, California, by killer whales previously identified in Glacier Bay, Alaska. Can. J. Zool., v. 72, n. 8, p. 1528-1530, 1994

HEYNING, J. E.; DAHLHEIM, M. E. Orcinus orca. Mamm. Species, v. 304, p. 1-9, 1988.

HOELZEL, A. R. Killer whale predation on marine mammals at Punta Norte, Argentina: food sharing, provisioning and foraging strategy. Behav. Ecol. Sociobiol., v. 29, n. 3, p. 197-204, 1991.

IÑÍGUEZ, M. A. Seasonal distribution of killer whales (Orcinus orca) in Northern Patagonia, Argentina. Aquat. Mamm., v. 27, n. 2, p. 154-161, 2001.

LODI, L.; HETZEL, B. Orcinus orca (Cetacea; Delphinidae) em águas costeiras do Estado do Rio de Janeiro. Bioikos v. 12, n. 1, p. $46-54,1988$.
LOPEZ, J. C.; LOPEZ, D. Killer whales (Orcinus orca) of Patagonia, and their behavior of intentional stranding while hunting nearshore. J. Mamm., v. 66, n. 1, p. 181183, 1985.

MATKIN, C. O.; MATKIN, D. R.; ELLIS, G. M.; SAULITIS, E.; MCSWEENEY, D. Movements of resident killer whales in Southeastern Alaska and Prince William Sound, Alaska. Mar. Mamm. Sci., v. 13, n. 3, p. 469-475, 1997.

OTT, P. H.; DANILEWICZ, D. Presence of franciscana dolphins (Pontoporia blainvillei) in the stomach of a killer whale (Orcinus orca) stranded in southern Brazil. Mammalia, v. 62, n. 4, p. 605-609, 1997.

PITMAN, R. L; ENSOR, P. Three forms of killer whales (Orcinus orca) in Antarctic waters. J. Cetacean Res. Mgmt, v. 5, n. 2, p. 131-139, 2003.

SANTOS, M. C. DE O.; NETTO, D. Killer whale (Orcinus orca) predation on a franciscana dolphin (Pontoporia blainvillei) in Brazilian waters. Latin Amer. J. Aquat. Mamm., v. 4, n. 1, p. 62-72, 2005.

SANTOS, M. C. DE O.; ROSSO, S. Ecological aspects of marine tucuxi dolphins (Sotalia guianensis) based on group size and composition in the Cananéia estuary, Southeastern Brazil. Latin Amer. J. aquat. Mamm., v. 6, n. 1, p. 71-82, 2007.

SANTOS, M. C. DE O.; ROSSO, S. Social organization of marine tucuxi dolphins (Sotalia guianensis) in the Cananéia estuary, southeastern Brazil. J. Mamm. v. 89, n. 2, p. 347-355, 2008.

SANTOS, M. C. DE O.; ACUÑA, L. B.; ROSSO, S. Insights on site fidelity and calving intervals of the marine tucuxi dolphin (Sotalia fluviatilis) in southeastern Brazil. J. mar. biol. Ass. U.K., v. 81, n. 6, p. 1049-1052, 2001.

SANTOS, M. C. DE O.; PACÍFICO, E. S.; GONÇALVES, M.F. Unusual record of franciscana dolphins (Pontoporia blainvillei) in inner waters of the Cananéia estuary, southeastern Brazil. Latin Amer. J. Aquat. Mamm., v. 6, n. 1, p. 117-119, 2007.

SECCHI, E. R.; VASKE JR., T. Killer whale (Orcinus orca) sightings and depredation of tuna and swordfish longline catches in southern Brazil. Aquat. Mamm., v. 24, n. 2, p. 117-122, 1998.

SICILIANO, S.; LAÍlLSON-BRITO JR., J; AZEVEDO, A. F. Seasonal occurrence of killer whales (Orcinus orca) in waters of Rio de Janeiro, Brazil. Mamm. Biol., v. 64, n.4, p. 251-255, 1999.

VISSER, I. N. Propeller scars on and known home range of two orca (Orcinus orca) in New Zealand waters. N. Z. Jl. mar. Freshwat. Res., v. 33, n. 4, p. 635-642, 1999.

(Manuscript received 03 June 2008; revised 16 September 2008; accepted 29 September 2008) 